\title{
The Analysis of Students' High Level Thinking Ability on Motion Systems Material on Covid Pandemic 19 at Madrasah Aliyah Medan City
}

\author{
Willyana Utari Siahaan ${ }^{1}$, Herbert Sipahutar ${ }^{2}$, Syahmi Edi ${ }^{3}$ \\ ${ }^{1}$ Postgraduate Program in Universitas Negeri Medan, Indonesia \\ ${ }^{2,3}$ Universitas Negeri Medan, Indonesia \\ willyanautari@gmail.com
}

\begin{abstract}
This study aims to: (1) Know the description of higher order thinking skills in the material of motion systems in students at MAN 1 Medan City. (2) Knowing the description of high-order thinking skills in the material of motion systems in students at MAL UINSU Medan City. (3) Knowing the differences in higher-order thinking skills in the material of motion systems in students at MAN 1 Medan and MAL UINSU Medan. (4) Knowing the learning process of the motion system during the COVID 19 pandemic at MAN 1 Medan and at MAL UINSU Medan. This research method uses a quantitative research type with a descriptive approach. The results showed: (1) Students 'high-order thinking skills on motion system material in class XI MAN 1 Medan City had an average score of 84.83 in a good category. (2) Students' high-order thinking skills on movement system material in class XI MAL UINSU Medan City average score of 82.17 with good category. (3) (1) Students 'high-order thinking skills on motion system material in class XI MAN 1 Medan City with an average score of 84.83 in the good category, (2) Students' high-order thinking skills on motion system material in class XI MAL UINSU Medan City an average score of 82.17 with good category. (3) With the Sig (2-tailed) value of 0.048 is smaller than the significant levels of 0.05 and $n t$ value $>t$ table (2.125> 2,048). (4) The highest indicator of students 'high-order thinking skills in class XI MAN 1 Medan City is creating, while the highest indicator of students' high-order thinking skills in class XI MAL UINSU Medan City.
\end{abstract}

Keywords

higher-order thinking ability; COVID 19; motion systems

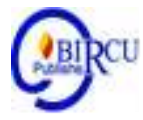

\section{Introduction}

On March 24, 2020 the Ministry of Education and Culture of the Republic of Indonesia issued Circular Number 4 of 2020 concerning the implementation of educational policies in the emergency period of the spread of Corona Virus Dosease (Covid-19), in this circular explaining JPTIK, Volume 5, Number 1 (2020) 2 about the Implementation of the Learning Process from Home (Online Learning). Face-to-face learning that is carried out at school / campus is converted into learning from home which is done online. This government effort has been followed by all schools and tertiary institutions in Indonesia including the Medan City MA which is implementing Online Learning (online) starting on March 24, 2020, which causes schools to carry out online learning activities for all students in Medan City. 
The ideal learning objective is to guide students to adapt in the real world, to become critical and creative thinkers, problem solvers, and decision makers. According to Resien (2020) learning is the process of changing behavior due to interactions among individuals and the environment. Based on a survey conducted by Casner (2006) on the needs of the world of work in the United States, critical thinking skills are in the first position. Other skills that stand out and are important according to the survey are mastery of information technology, the ability to think collaboratively, and be innovative (Magsino, 2014). The meaning of the survey results for our education world is that students must be able to master higher order thinking skills. In line with the survey results, children must be challenged to think, find problems, find alternative solutions, and be able to solve them.

One of the problems facing the world of education today is the problem of the weak implementation of the online learning process applied by teachers in schools. The online learning process that has occurred so far has not been able to develop students' higher order thinking skills. The implementation of the learning process that takes place online is only directed at the student's ability to memorize information, the student's brain is forced to remember and accumulate various information without being required to understand the information obtained to relate it to situations in everyday life.

Another problem with the online learning process in Biology in SMA / MA is that there are still many teachers who only provide material without explanation and analysis of the material, so that students do not understand what the teacher says through online learning. The teachers have not fully carried out active and creative learning in involving students and have not used various learning strategies that vary based on the character of the subject matter. Most teachers are only fixated on textbooks as the only source of teaching and learning (Rahmat and Soesilawaty, 2014). For this reason, in each lesson the teacher is required to be able to provide learning and arrange questions to higher level thinking abilities.

Learning oriented to higher-order thinking skills is learning that involves 3 aspects of higher-order thinking skills, namely: transfer of knowledge, critical and creative thinking, and problem solving. In the process of learning high-order thinking skills, regardless of the KD level, whether the $\mathrm{KD}$ is at the $\mathrm{C} 1, \mathrm{C} 2, \mathrm{C} 3, \mathrm{C} 4, \mathrm{C} 5$, or $\mathrm{C} 6$ level.

In online learning, it may be very difficult to apply higher-order thinking skills-based learning, but that does not mean it cannot be in the midst of limited circumstances. As a teacher, you can design meaningful learning that can involve students in these learning activities. Teachers can apply ICT and TPACK in virtual classroom learning. Animated videos and PHET simulations are things that can help teachers implement high-level learning skills. Students need to be accustomed to learning based on high-level learning abilities because students need to have 21 st century learning skills that are needed as capital in the future.

Solang's (2008) research results reinforce the statements of Joni, Wardani and Nugraheni (in general learning today is teacher centered, unable to develop critical thinking, problem-solving, creative, and responsible thinking skills), where students are intervened or trained in practical thinking. -synthetic-analytic (critical and creative thinking) has a higher performance than those who are not trained in practical-synthetic and analytical thinking (Karmana, 2013). Anggraini and Sriyati (2019) previously concludedthat the high order thinking skills of class X students in Kota Solok are still "lacking", because The average achievement of students' high-order thinking skills in Solok city only reached $32.08 \%$. Accredited school A received a percentage score of $39.41 \%$ and school accredited B received a percentage score of $26.01 \%$.So the percentage of students' high level thinking ability in the city of Solok is $32.08 \%$ (very low $\leq 54 \%$ ). 
According to Prasasti (2019) the use of technology media provides benefits for teachers and students to access learning materials and interact directly in learning in the classroom, and also outside the classroom through online media. In the learning process, students are less encouraged to develop thinking skills (Permanasari, 2013). However, many biology lessons in the classroom have not taken advantage of students' higher order thinking skills (Luthfiana, 2013).

Given the high-order thinking skills of students are very important in dealing with online learning problems in the current era of the COVID-19 pandemic and the importance of higher-order thinking skills for students, the authors are interested in conducting a study entitled: "Analysis of Students' High-Level Thinking Ability on Material. The Movement System during the COVID 19 Pandemic in Medan City MA ".

\section{Review of Literatures}

\subsection{The Nature of Learning Biology}

Biology studies the physical structure and function of the organs of the human body and studies the environment. And has a peculiarity in developing logical thinking through classification. A biology teacher needs to motivate students to enjoy learning biology, provide reinforcement and show that learning biology is not good by memorizing. The following are characteristics of science, among others (Rustaman, 2003):

$>$ The object of study is in the form of a concrete object and can be captured by the senses.

$>$ Developed based on empirical experience (real experience).

$>$ Has standardized systematic steps.

$>$ Using a logical way of thinking, which is deductive, means thinking by drawing conclusions from general things into special provisions.

$>$ The result is laws that are generally accepted, wherever applicable.

Biology is also a branch of science that studies the problems of living things. In studying science it consists of 3 components, namely:

1. Scientific Attitude

It is a must-have attitude to be objective when collecting and analyzing data.

2. Scientific Process

There are process skills which consist of:

- Observing: Looking for a picture or information about the object of research through the senses.

- Classifying: To make it easier to identify a problem.

- Interpreting: Gives the meaning of a phenomenon / event based on other occurrences.

- Putting into practice: Estimating events based on previous events and applicable laws.

3. Scientific Product

By using scientific attitudes and processes, experts make discoveries that can be facts or theories. Scientific products are very influential on the development of science and technology. The biology curriculum provides a variety of learning experiences, for understanding scientific concepts and processes. The functions and objectives of biology subjects are to instill awareness of the beauty and order of nature, so that students can increase their mastery of science and technology. The objectives in studying biology are:

$>$ Understand the concepts and the interrelationship between each other.

$>$ Develop basic biology skills to foster scientific values and attitudes.

Apply biological concepts to produce technological works related to human needs. 


\subsection{Higher Level Thinking Ability}

Higher-order thinking skills are a thinking process that is not just memorizing and relaying known information and the ability to connect, manipulate, and transform existing knowledge and experience to think critically and creatively in an effort to make decisions and solve problems in new situations (Rofiah et al, 2013).

High-order thinking skills, according to Brookhart (2010: 5), are high-order thinking at the top of Bloom's cognitive taxonomy, the goal of teaching behind the cognitive taxonomy that can equip students to transfer knowledge, being able to think means students are able to apply knowledge and skills. which they develop during learning in new contexts. In this case what is meant by "new" is the application of concepts that have not been thought of by students before, but the concept has been taught, this means that it is not necessarily something new. Higher order thinking means the ability of students to connect learning with other things that have not been taught.

According to Gunawan in Lailly and Wisudawati (2015), higher-order thinking skills include aspects of critical thinking skills, creative thinking skills, and problem-solving abilities. Critical thinking is the ability to analyze, create and use criteria objectively, and evaluate data. Creative thinking is the ability to use complex thinking structures so as to come up with new and original ideas. The ability to solve problems is the ability to think in complex and deep ways to solve a problem.

According to Newman and Wehlage in Lusyana and Wangge (2016), with highorder thinking skills students will learn more deeply, students will understand concepts better. This is in accordance with the substantive character of a lesson when students are able to demonstrate their understanding well and deeply. With high-order thinking skills students can clearly distinguish ideas or ideas, argue well, be able to solve problems, be able to construct explanations, are able to hypothesize and understand complex matters more clearly.

Based on some of the definitions of higher-order thinking skills above, it can be concluded that higher-order thinking skills are a person's ability to criticize, solve complex problems and can provide various solutions to the solution of manipulating the data he gets. Indicators of Higher Order Thinking Skill (HOTS) or high-order thinking skills that can be used are (a) the level of analysis is an ability based on the description of the material into a component and various factors and the ability to understand the relationship between a cause and effect so that in learning that students have more ability to solve a problem (Krathwohl, 2002: 230); (b) the evaluation level is the ability to make decisions based on criteria through a level consisting of checking and critical skills; and (c) the level of creating this. Learners organize a variety of information using different ways or than usual.

\subsection{Frame work}

The thinking ability of students is included in the cognitive realm. The thinking ability is then divided into several stages to determine the level of thinking abilities of students. The figure who first suggested the division of the stages of students' thinking abilities was Benjamin S. Bloom. According to Benjamin S. Bloom, students' cognitive domain is divided into six stages, namely: knowledge, comprehension, application, analysis, synthesis, and evaluation. The keenem of this stage is known as "Bloom's Taxonomy". Furthermore, the bloom taxonomy is divided into two parts, namely: highorder thinking skills and low-order thinking skills. Memorizing knowledge, understanding or comprehension, applications fall into the category of low-level thinking skills. Meanwhile, analysis, synthesis, and evaluation are included in higher order thinking skills. 
The current problem in learning is the condition of the COVID 19 pandemic which has changed the learning method in the form of online learning. In biology learning, one of them is the low level of student learning activities in the learning process, this happens because the teacher still emphasizes the material thoroughly so that student learning activities have not received a balanced portion in the period before the COVID 19 pandemic. Therefore competence in scientific learning has not been achieved. Learning problems were also increasingly seen during the COVID 19 pandemic, where teachers did not master good learning methods for online learning.

Efforts are needed to improve online learning in biology subjects by applying higherorder thinking skills to student learning activities so that student learning outcomes are better. The thinking framework of this research begins with providing biology learning on the material of motion systems. After being given the teaching material by delivering biology learning material online, the learning process will apply a high level of learning ability, namely analyzing, synthesizing and evaluating the learning process.

\section{Research Methods}

This type of research is a quantitative study with a descriptive approach. The population in this study were all students of class XI MIA Madrasyah Aliyah Medan City. The sample in this study is representative of the population of class XI MIA Madrasyah Aliyah Medan City students, namely 30 students from MAN 1 Medan and 30 students from MAL UIN SU Medan City. The sampling technique used in this study was purposive sampling. This research was conducted at Madrasah Aliyah Medan City. The research data were collected using test techniques, observation (observation) and document study. Test techniques and observation techniques are used to collect data related to higher order thinking skills, while document study techniques are used to collect data on student learning outcomes. The trial data were then analyzed to see the validity, reliability, distinguishing power, and the level of difficulty of the test instrument. After the data I need is collected, the next step is to analyze the data using Microsoft Excel version 13 and the SPSS $\mathrm{v}$ application. 25. The normality test is used for preliminary analysis and is a prerequisite for hypothesis testing (Kadir, 2015, p. 144). The homogeneity test was carried out to determine the homogeneity of the data on high-order thinking skills and students' biology learning outcomes. The research hypothesis testing was carried out using the Independent sample t-test with the help of SPSS version 25. The normality test is used for preliminary analysis and is a prerequisite for hypothesis testing (Kadir, 2015, p. 144). The

homogeneity test was carried out to determine the homogeneity of the data on high-order thinking skills and students' biology learning outcomes. The research hypothesis testing was carried out using the Independent sample t-test with the help of SPSS version 25. The normality test is used for preliminary analysis and is a prerequisite for hypothesis testing (Kadir, 2015, p. 144). The homogeneity test was carried out to determine the homogeneity of the data on high-order thinking skills and students' biology learning outcomes. The research hypothesis testing was carried out using the Independent sample t-test with the help of SPSS version 25. 


\section{Discussion}

\subsection{High Level Thinking Ability of Students in Motion Systems Material in Class XI}

Students of MAN 1 Medan City

Descriptive data of high-order thinking skills of class XI MAN 1 Medan City students in the biology subject matter of motion systems is shown in Table 4.1 (in Appendix 7). The data came from 30 students of class XI MAN 1 Medan and expressed in the form of a converted score on a scale of $0-100$.

Table 1. Description Higher-Order Thinking Ability Data Class XI Students of MAN 1 Medan City on the Material of Motion Systems.

\begin{tabular}{lc}
\hline Parameter & Description \\
\hline Lowest score & 80.00 \\
\hline The highest score & 90.00 \\
\hline Average & 84.83 \\
\hline Median & 85.00 \\
\hline Mode & 80.00 \\
\hline Standard Deviation & 4.52 \\
\hline Total students & 30 \\
\hline
\end{tabular}

The table above shows that the average score of students' high-order thinking skills in class XI MAN 1 Medan is 84.83 with a standard deviation value of 4.21 . Then the data categorization of high-order thinking skills scores was carried out in class XI MAN 1 Medan, which aims to place respondents into tiered categories, namely: good enough, good and very good.

Table 2. Distribution (\%) of Class XI Students of MAN 1 Medan City Based on the Higher Level Thinking Ability Category on the Material of Motion Systems

\begin{tabular}{cccc}
\hline Higher Level Thinking Ability & & Percentage (\%) \\
\cline { 1 - 1 } Score & Category & Frequency & Total \\
\hline $80-85$ & Good & 20 & 66.7 \\
\hline 90 & Very good & 10 & 33.3 \\
\hline Total & & 30 & 100 \\
\hline
\end{tabular}

The table above shows that the percentage of students in MAN 1 Medan City have high-level thinking skills with good and very good categories with a ratio of $66.7 \%$ : $33.3 \%$. If the data on students' high-order thinking skills scores are analyzed per component (indicator) of higher order thinking, namely the components of the ability to analyze (C4), evaluate (C5) and the component of the ability to create (C6), then the average score of the sample group students can be seen in Table 3. and Table 6.

Table 3. Average Score High Level Thinking Ability of Class XI MAN 1 Students on the Material of Motion Systems for Each Indicator.

\begin{tabular}{lcc}
\hline $\begin{array}{l}\text { Indicator Higher Level } \\
\text { Thinking Ability }\end{array}$ & $\begin{array}{l}\text { Average Score Higher Level } \\
\text { Thinking }\end{array}$ & Cbility \\
\hline Ability to analyze (C4) & 83.81 & Good \\
\hline Ability to evaluate (C5) & 84.44 & Good \\
\hline Ability to create (C6) & 86.19 & Good \\
\hline Average & 84.81 & Good \\
\hline
\end{tabular}


In the table above, it is clear that the average score of students is more or less the same for each indicator of Higher-Order Thinking Ability. Even though the students' scores on the ability to create indicators (C6) tend to be higher (86.19) than other indicators, this difference is not far from the average number (84.81), and all of them are still in the Thinking Ability category. High Level is good.

\subsection{High Level Thinking Ability of Students on the Material of Motion Systems in Class XI MAL UIN SU Medan City}

Descriptive data of high-order thinking skills of class XI MAL UIN SU Medan City in the biology subject matter of motion systems is shown in Table 4 below. The data came from 30 students of class XI MAL UIN SU Medan and expressed in the form of a converted score on a scale of $0-100$.

Table 4. Description Higher-Order Thinking Ability Data Class XI MAL Students at UIN SU Medan City on the Material of Motion Systems.

\begin{tabular}{lc}
\hline Parameter & Description \\
\hline Lowest score & 70.00 \\
\hline The highest score & 90.00 \\
\hline Average & 82.17 \\
\hline Median & 80.00 \\
\hline Mode & 80.00 \\
\hline Standard Deviation & 5.83 \\
\hline Total students & 30 \\
\hline
\end{tabular}

The table above shows that the average score of high-order thinking skills of class XI MAL UIN SU Medan is 82.17 with a standard deviation value of 5.83. Then the data categorization of high-order thinking skills scores on students of class XI MAL UIN SU Medan City, this aims to place respondents into tiered categories, namely: good enough, good and very good. The categorization of high order thinking skills scores of students at MAL UIN SU Medan is presented in Table 5. below.

Table 5. Distribution (\%) Students of Class XI MAL UIN SU Medan City Based on the Category of High-Level Thinking Ability in the Material of Motion Systems

\begin{tabular}{ccccc}
\hline Higher Level Thinking Ability & & Percentage (\%) \\
\cline { 5 - 5 } Score & Category & Frequency & Total \\
\hline $70-75$ & Pretty good & 5 & 16.7 \\
\hline $80-85$ & Good & 18 & 60.0 \\
\hline 90 & Very good & 7 & 23.3 \\
\hline Total & & 30 & 100 \\
\hline
\end{tabular}

The table above shows that the percentage of MAL UIN SU students in Medan City has high-level thinking skills in quite good, good and very good categories with a ratio of 16.7\%: $60 \%: 23.3 \%$. 
Table 6. Average Score Higher Level Thinking Ability Class XI MAL Students of UIN SU Medan City on the Material of Motion Systems for Each Indicator

\begin{tabular}{lcc}
\hline $\begin{array}{l}\text { Indicator Higher Level } \\
\text { Thinking Ability }\end{array}$ & $\begin{array}{c}\text { Average Score Higher Level } \\
\text { Thinking Ability }\end{array}$ & Category \\
\hline Ability to analyze (C4) & 83.81 & Good \\
\hline Ability to evaluate (C5) & 80.00 & Good \\
\hline Ability to create (C6) & 82.40 & Good \\
\hline Average & 82.06 & Good \\
\hline
\end{tabular}

In the table above, it is clear that the average score of students is more or less the same for each indicator of Higher-Order Thinking Ability. Even though the students' scores on the indicator of ability to analyze (C4) tend to be higher (83.81) than other indicators, this difference is not far from the average number (82.06), and all of them are still in the Thinking Ability category. High Level is good.

\subsection{Differences in High-Level Thinking Ability of Students in the Material of Motion} Systems in students at MAN 1 Medan and students at MAL UINSU Medan a. Pre requisite Test

This test, consisting of a normality test and a data homogeneity test, is performed as a prerequisite for hypothesis testing.

\section{b. Normality Test}

The normality test was carried out using the Liliefors test (SPSS v. 25 program) with the test results that the two data sets were normally distributed.

Table 7. Normality Test

\begin{tabular}{|c|c|c|}
\hline \multirow{2}{*}{$\begin{array}{l}\text { Data on Students' High } \\
\text { Level Thinking Ability }\end{array}$} & \multicolumn{2}{|c|}{ Kolmogorf-Smirnov } \\
\hline & $\boldsymbol{\alpha}$ & Asym. Sig. \\
\hline MAN sample 1 & \multirow{2}{*}{0.05} & 0.200 \\
\hline Sample MAL UIN SU & & 0.200 \\
\hline Terms & \multicolumn{2}{|c|}{$\begin{array}{l}\text { If Asymp. Sig }>0.05 \text {, then the data is normally } \\
\text { distributed }\end{array}$} \\
\hline Conclusion & \multicolumn{2}{|c|}{$\begin{array}{l}\text { The results of the normality test for the two } \\
\text { variables were not normally distributed }\end{array}$} \\
\hline
\end{tabular}

Due to the Asymp value. Sig that is greater than 0.05 , it is concluded that the two groups of the study sample were normally distributed.

\section{c. Homogeneity Test}

The homogeneity test was performed using the Levene Statistics test (SPSS v. 25 Program) and the results are presented in Table 8 . below.

Table 8. Homogeneity Test

\begin{tabular}{|c|c|c|c|c|}
\hline \multirow{2}{*}{\multicolumn{2}{|c|}{ Data }} & & \multicolumn{2}{|c|}{ Kolmogorf-Smirnov } \\
\hline & & & A & Asym. Sig. \\
\hline $\begin{array}{l}\text { Higher } \\
\text { Ability }\end{array}$ & Level & Thinking & 0.05 & 0.087 \\
\hline Terms & & & If Asymp. Sig> & e variance \\
\hline
\end{tabular}




\begin{tabular}{ll}
\hline Conclusion & (homogeneous) \\
\hline & $\begin{array}{l}\text { The results of the homogeneity test for the two } \\
\text { groups of the study sample had the same variance } \\
\text { (homogeneous) }\end{array}$ \\
\hline
\end{tabular}

Because the table above shows that the sig. High Level Thinking Ability of students in both groups of the study sample is greater than 0.05 ,

it is concluded that the two groups of this study sample have the same or homogeneous variance. The prerequisite test for normality and homogeneity has been fulfilled with the two research groups having data that is normally distributed and the same or homogeneous variance, so it can be continued with hypothesis testing.

\section{d. Hypothesis Testing}

Hypothesis testing is carried out after the prerequisite test, namely the $t$ test in the independent $\mathrm{T}$ test, to see the differences between the study sample groups (Appendix 11). This test, carried out with the help of SPSS v. 25, aimed at revealing the correlation or relationship between higher order thinking skills and learning outcomes variables.

The results of the homogeneity test for the two groups of the study sample had the same (homogeneous) variance the use of the $t$ test uses the equal variance assumed (assuming the two variants are the same). Based on Table 4.9, the data can be analyzed that the Sig (2-tailed) value of 0.048 is smaller than the significant level of 0.05 with nt value> t table (2.125> 2.048), so Ho is rejected, meaning that there is a difference between the average high-order thinking skills in the motion system material between students in class XI MAN 1 Medan City and class XI MAL UIN SU Medan City. In the Group Statistics table (almpiran 11), it can be seen that the average (mean) high-order thinking ability of students for class XI MAN 1 Medan City is 84.83 and for XI MAL UIN SU Medan City is 82.17 meaning that the average high-order thinking ability Class XI students of MAN 1 Medan City are higher than the average high-order thinking ability of class XI MAL students of UIN SU Medan Cityit means that H0 is rejected and H1 is accepted. So that the research results obtained a significant differencehigh-order thinking skills on the material of motion systems between students in class XI MAN 1 Medan City and class XI MAL UIN SU Medan City.

\section{Conclusion}

Based on the results of data analysis and discussion in the previous chapter, it can be concluded that:

a. Students' high-order thinking skills on motion system material in class XI MAN 1 Medan City average score of 84.83 with good category.

b. Students' high-order thinking skills on the motion system material in class XI MAL UIN SU Medan City average score of 82.17 with good category.

c. There is a difference between the average high-order thinking skills in the motion system material between students in class XI MAN 1 Medan City and class XI MAL UINSU Medan City students. WithThe Sig (2-tailed) value of 0.048 is smaller than the significant levels of 0.05 and $n t$ value> t table $(2.125>2,048)$.

d. The highest achievement of the Bloom Taxonomy indicator in the high-level thinking ability of the sample group in the class of MAN 1 Medan City is to create at $86.19 \%$, then to evaluate it is $84.44 \%$ and the lowest is to analyze at $83.81 \%$. 
Meanwhile, the highest achievement of the Bloom Taxonomy indicator in the highlevel thinking ability of the sample group in the MAL class of UIN SU Medan City was to analyze $83.81 \%$, then to create $82.38 \%$ and the lowest to evaluate $80 \%$. This difference shows that during the COVID 19 epidemic, students of MAN 1 Medan City had high-level thinking skills that were good in the online learning process on the motion system material than MAL students at UIN SU Medan City.

\section{References}

Angraini, G. \& Sriyati, S. (2019) Analisis Kemampuan Berpikir Tingkat Tinggi Siswa SMA N Kelas X di Kota Solok Pada Konten. Biologi. Journal of Education Informatic Technology and Science (JeITS), 1 (1): 114-124.

Brookhart, S.M. (2010). How to Assess Higher Order Thinking Skill in Your Classroom. Alexandria, Virginia: ASCD.

Casner-Lotto J. \& Barrington L. (2006). Are They Really Ready To Work? Employers' Perspectives on the Basic Knowledge and Applied Skills of New Entrants to the 2lth Century U.S. Worksforce.

Karmana, I.W. (2013). Memberdayakan Berpikir Tingkat Tinggi (Higher Order Thinking) Siswa SMA dalam Pembelajaran Biologi. Jurnal Prisma Sains, 1 (1): 55-65.

Lailly, N.R. \& Wisudawati, A.W. (2015). Analisis Soal Tipe Higher Order Thinking Skill (HOTS). Kaunia, 9 (1):27- 39

Lusyana, E. \& Wangge, M. (2016). Increasing Higher Order Thinking Skill to Build Studentses Character by Using Mathematical Reasoning. Proceeding of 3rd International Conference on Research, Implementation and Education Of Mathematics And Science, p:119-126.

Luthfiana. (2013). Penerapan Strategi Brain Based Learning yang Dapat Meningkatkan Keterampilan Berpikir Tingkat Tinggi. Jurnal Pendidikan Matematika Universitas Negeri Malang.

Magsino, R.M. (2014). Enhancing Higher Order Thinking Skills in a Marine Biology Class through Problem-Based Learning. Asia Pacific Journal of Multidisciplinary Research, 2 (5): 1-6.

Permanasari, V. (2013). Efektivitas Pendekatan Pembelajaran Open-Ended terhadap Kemampuan Berpikir Matematis Siswa pada Materi Trigonometri Ditinjau dari Kreativitas Belajar Matematika Siswa. Jurnal Pendidikan Matematika Solusi,1 (1): $1-7$.

Prasasti, T.I., Solin, M., and Hadi, W. (2019). The Effectiveness of Learning Media Folklore Text of North Sumatera Based on Blended Learning by $10^{\text {th }}$ Grade Students of Vocational High SchoolHarapan Mekar-1 Medan. Budapest International Research and Critics in Linguistics and Education (BirLE) Journal Vol 2 (4): 480490.

Rahmat, A. \& Soesilawaty, S.A. (2014). Beban Kognitif Kemampuan Berfikir Interdisiplin Siswa SMA dalam Pembelajaran Biologi terhubung Berbasis Dimensi Belajar. Jurnal Ilmu Pendidikan, 20 (1): 66-74.

Resien, Sitompul, H., and Situmorang, H. (2020). The Effect of Blended Learning Strategy and Creative Thinking of Students on the Results of Learning Information and Communication Technology by Controlling Prior Knowledge. Budapest International Research and Critics in Linguistics and Education (BirLE) Journal Vol 3 (2): 879-893. 
Rofiah, E., Aminah, N.S. \& Ekawati, E.Y. (2013). Penyusunan Instrumen Tes Kemampuan Berpikir Tingkat Tinggi Fisika pada Siswa SMP. Jurnal Pendidikan Fisika, 1 (2): 17-22.

Rustaman, N.Y., Dirjosoemarto, S. Yudianto, S.A., Achmad, Y., Subekti, R., Rochintaniawati, D., Nurjani,M.K. (2003). Strategi BelajarMengajarBiologi. Jakarta: Univerditas Pendidikan Indonesia

Solang, D.J. (2008). Latihan Keterampilan Intelektual dan Kemampuan Pemecahan Masalah Secara Kreatif. Jurnal Ilmu Pendidikan, 15 (1): 35-42. 